\title{
Analisis Kelayakan Finansial Pembangunan Koneksi Pelabuhan Kapal Ro-Ro Dumai-Malaka Metode Deterministik
}

\author{
Financial Feasibility Analysis Development of Ro-Ro Ship Port Connections Dumai-Malacca \\ Deterministic Method
}

\author{
Yoga Budi Pratama \\ Teknik Sipil, Universitas Riau, Jl. HR Soebrantas KM. 12,5, Pekanbaru, Indonesia
}

\author{
* Penulis korespondensi : yogabudi24okt@gmail.com \\ Tel.: +62-823-8694-2865 \\ Diterima: 29 September 2021; Direvisi: 31 Oktober 2021; Disetujui: 31 Oktober 2021 \\ DOI: XX.XXXX/saintis201X.X.X.00X
}

\section{Abstrak}

Dalam rangka mendorong pengembangan kawasan implementasi Masyarakat Ekonomi ASEAN (MEA) Pelabuhan Penyeberangan RoRo Dumai-Melaka menjadi salah satu dari tiga Pelabuhan Penyeberangan Ro-Ro yang akan diprioritaskan pengembangannya. Dalam rangka merealisasikan program tersebut, perlu dilakukan persiapan berupa penyediaan fasilitas pokok dan fasilitas yang akan menggunakan pendanaan/investasi yang besar. Adapun tujuan dilakukan penelitian adalah melakukan analisa kelayakan finansial dengan pendekatan deterministik (single point estimate) dan mengidentifikasi variabel yang paling sensitif (berpengaruh) terhadap finansial rencana pembangunan rute koneksi kapal Ro-Ro Dumai-Malaka sekaligus seberapa besar pengaruhnya sehingga dapat menjadi referensi skenario solusi pengambilan keputusan yang dapat diambil oleh pemerintah, badan usaha maupun investor secara komprehensif dalam melakukan investasi terhadap rencana pembangunan rute koneksi kapal Ro-Ro Dumai-Malaka. Besar total investasi adalah Rp. 56.702.000.000,00 dengan umur rencana proyek selama 30 tahun. Metode analisa kelayakan finansial yang dipakai melalui pendakatan deterministik. Berdasarkan hasil Net Present Value/NPV bernilai negatif dengan nilai NPV adalah Rp.11.520.600.000 pada akhir umur rencana. Selanjutnya berdasarkan dari perhitungan Internal rate of return (IRR) didapatkan nilai IRR 3,75\% dimana nilai ini lebih kecil dari nilai discount rate yaitu 4,92\%. Dan berdasarkan hasil Benefit Cost Ratio (BCR) didapat nilai BCR 0,832 (BCR<1). Berdasarkan hasil analisa sensitivitas diketahui variabel yang paling sensitif (berpengaruh) adalah biaya konstruksi dermaga dan fasilitas pelabuhan. Dari hasil tersebut dapat dinyatakan bahwa rencana pembangunan rute koneksi kapal Ro-Ro DumaiMalaka tidak layak secara finansial.

Kata Kunci: Kapal Ro-Ro, Analisa Finansial, Deterministik, Analisa sensitivitas

\begin{abstract}
In order To encourage the development of the ASEAN Economic Community (MEA) implementation area, the Dumai-Melaka Ro-Ro Ferry Port is one of the three Ro-Ro Ferry Ports that will be prioritized in the development. In order to be able to realize the program it is necessary to make preparations in the form of basic facilities and facilities that require a lot of money/investments. The aim of this research is to analyze the financial feasibility with a deterministic approach (one-point estimate) and to identify the most sensitive (influential) variable on the financial plan for the construction of the Dumai-Malacca Ro-Ro ship connection route and how much influence it so that it can be a reference for solution-making scenarios decisions that can be made by the government, companies and investors to invest comprehensively in the planned construction of the Dumai-Malacca Ro-Ro ship connection route. The total investment is Rp. $56,702,000,000.00$ with a project duration of 30 years. The method used for financial feasibility analysis is through a deterministic approach. Based on the results the net present value/NPV is negative with an NPV value of Rp 11,520.6 million at the end of the term. In addition, based on the internal rate of return (IRR) calculation, an IRR value of $3.75 \%$ was obtained where this value is less than the discount rate value of $4.92 \%$. And based on the results of the Benefit Cost Ratio (BKR), a BKR value of 0.832 (BKR<1) was obtained. Based on the results of the sensitivity analysis, it is known that the most sensitive (influential) variable is the cost of constructing docks and port facilities. Hence it is summary that was the planned construction of the Ro-Ro ship connection route Dumai-Malacca is not financially feasible to performed.
\end{abstract}

Keywords: Ro-Ro Ship, Financial Analysis, Deterministic, Sensitivity Analysis

\section{PENDAHULUAN}

Negara ASEAN sepakat menetapkan delapan jaringan pelayaran kapal ferry Ro-Ro dalam rangka mendorong pengembangan kawasan implementasi Masyarakat Ekonomi ASEAN (MEA) yang menjadi fokus negara-negara ASEAN di bidang transportasi[1]. Selanjutnya ditetapkan tiga rute utama ASEAN Ro-Ro (Roll On-Roll Off) Network and Short Sea Shipping Asean Connectivity. Ketiga rute kapal Ro-Ro itu ialah Dumai-Malaka, BelawanPenang-Phuket, dan General Santos-Bitung[2].

Pada rute kapal Ro-Ro lintas Bitung-Davao Santos City, belum mempertimbangkan pengembalian investasi dan kelayakan finansial [3]. Sementara Untuk rute kapal Ro-Ro Belawan Penang-Phuket, Pelabuhan Belawan Medan sudah tidak melayani pelayaran ke Malaysia dikarenakan imbas harga transportasi udara murah [4]. Dari hasil tersebut, dapat dikatakan bahwa rute 
Belawan-Penang-Phuket, dan General SantosBitung tidak layak secara finansial.

Untuk rencana rute koneksi Kapal Ro-Ro Dumai-Malaka, perlu dilakukan persiapan berupa penyediaan fasilitas pokok dan fasilitas penunjang Koneksi Kapal Ro-Ro yang akan menggunakan pendanaan/investasi yang besar. Dengan nilai investasi yang besar, maka pembangunan pelabuhan untuk rute koneksi Kapal Ro-Ro DumaiMalaka mempunyai resiko dan ketidakpastian yang berpengaruh terhadap investasi proyek yang akan sangat berpengaruh terhadap kelayakan finansial proyek. Resiko dan ketidakpastian ini disebabkan oleh berbagai faktor seperti masalah regulasi bilateral, kebijakan pemerintah, kondisi ekonomi nasional dan global, serta factor berpengaruh lainnya. Resiko dan ketidakpastian pada rencana pembangunan rute koneksi kapal Ro-Ro DumaiMalaka akan sangat berpengaruh terhadap kelayakan finansial proyek. Ada beberapa variabel internal dan eksternal seperti: biaya, demand, kapasitas volume jasa pelabuhan, tarif dasar dan indikator ekonomi yang dapat sangat mempengaruhi pengembalian investasi sehingga dapat membuat proyek ini berkemungkinan tidak layak secara finansial, sehingga analisis variabel yang sensitif (berpengaruh) sangat diperlukan agar dapat membantu dalam pengambilan keputusan dalam investasi sehingga diperlukan analisa kelayakan finansial rencana pembangunan koneksi kapal Ro-Ro Dumai-Malaka.

Adapun tujuan dilakukan penelitian adalah melakukan analisa kelayakan finansial dengan pendekatan deterministik (single point estimate) dan mengidentifikasi variabel yang paling sensitif (berpengaruh) terhadap finansial rencana pembangunan rute koneksi kapal Ro-Ro DumaiMalaka sekaligus seberapa besar pengaruhnya.

Manfaat dari penelitian ini adalah sebagai skenario solusi pengambilan keputusan yang dapat diambil oleh pemerintah, badan usaha maupun investor secara komprehensif dalam melakukan investasi terhadap rencana pembangunan rute koneksi kapal Ro-Ro Dumai-Malaka.

\section{Kapal Ro-Ro}

Kapal Roll-On Roll-Off (Ro-Ro) adalah kapal yang bisa memuat kendaraan yang berjalan masuk kedalam kapal dengan sendiri dan bisa keluar dengan sendiri sehingga kapal dilengkapi dengan pintu ramp yang dihubungkan moveble bridge atau jembatan langsung ke dermaga [5]. Kapal Ro-Ro dibagi dalam 3 kelompok, yaitu Ro-Ro Passenger (Road Haulage, unit no tourist/passenger), Ro-Ro Container, dan Ro-Ro other cargo. Dari pembagian kelompok kapal Ro-Ro tersebut, tipe kapal ini tidak hanya dapat mengangkut muatan di atas kendaraan beroda seperti truk, tapi juga petikemas dan muatan lain sehingga pemuatan menggunakan kapal Ro-Ro sangat bermanfaat[6].

\section{Analisa Kelayakan Finansial}

Analisis finansial merupakan suatu analisis yang membandingkan antara biaya dan manfaat untuk menentukan apakah suatu pekerjaan akan menguntungkan selama umur pekerjaan berlangsung [7]. Sekalipun aspek lain tergolong layak jika studi aspek finansial memberikan hasil yang tidak layak, maka usulan proyek akan ditolak [8].

Secara umum, analisis kelayakan finansial harus memuat kajian kelayakan proyek secara keuangan, dengan memberikan gambaran secara jelas terhadap kinerja keuangan dari sudut pandang penerimaan dan pengeluaran keuangan proyek, termasuk risiko yang akan dihadapi selama siklus proyek (project viability). Lebih lanjut, analisis kelayakan finansial mencakup biaya yang dibutuhkan selama siklus proyek (life-cycle costs) beserta kerangka waktunya biaya investasi/modal, pengadaan tanah, biaya konsultasi, dan biaya operasi dan pemeliharaan. Selain itu, terdapat juga opsi penerimaan dan perkiraan aliran penerimaan [9]. Beberapa hal lain yang harus diperhatikan dalam analisis finansial ialah waktu didapatkannya returns atau kembalinya modal sebelum pihakpihak yang berkepentingan dalam pembangunan proyek kehabisan modal [10].

\section{Aliran Arus Kas (Cashflow)}

Cash flow merupakan arus kas atau aliran kas yang ada diperusahaan atau dalam sebuah kegiatan dalam periode tertentu[11]. laporan arus kas (statement of cash flows) adalah sebuah laporan yang menggambarkan arus kas masuk dan arus kas keluar secara terperinci dari masing-masing aktivitas, yaitu mulai dari aktivitas operasi, aktivitas investasi, sampai pada aktivitas pendanaan/ pembiayaan untuk satu periode tertentu[12]. Aliran arus kas dalam suatu proyek dapat dikelompokkan menjadi 3 bagian, yaitu kas awal, kas operasional dan kas akhir[11].

\section{Net Present Value (NPV)}

Net Present Value dari sebuah proyek adalah merefleksikan nilai sekarang dari arus kas yang diharapkan diperoleh dari proyek tersebut, dikurangi dengan besarnya investasi yang dibutuhkan, dimana Suatu investasi dikatakan menguntungkan (profitable)/layak jika memilki nilai NPV positif (NPV>0) [13]. Rumus untuk meghitung Net Present Value adalah :

$$
N P V=\sum_{t=1}^{n} \frac{B t-C t}{(1+i)^{\wedge} t}
$$




\section{Internal Rate of Return (IRR).}

Arus pengembalian internal (internal rate of return) adalah arus pengembalian yang menghasilkan NPV aliran kas masuk = NPV aliran kas keluar. Pada metode NPV analisis dilakukan dengan menentukan terlebih dahulu besar arus pengembalian (diskonto/discount rate) (i), kemudian dihitung nilai sekarang netto (PV) dari aliran kas masuk dan kas keluar. Untuk IRR ditentukan dulu NPV=0, kemudian cari berapa besar arus pengembalian (diskonto/discount rate) (i), agar hal tersebut terjadi[7]. Adapun rumus yang digunakan adalah :

$\sum_{t=0}+\frac{A t}{(1+\mathrm{r}) \mathrm{t}}=0$

Menganalisis suatu usulan proyek dengan IRR akan didapat petunjuk bahwa :

(1) IRR > Tingkat suku bunga maka proyek diterima

(2) IRR < Tingkat suku bunga maka proyek ditolak

\section{Benefit Cost Ratio (BCR).}

Konsep BCR menekankan pada segi manfaat (benefit) bagi kepentingan proyek. Sebagai indikasi analisis ini adalah bila BCR lebih besar satu $(\mathrm{BCR}>1)$, maka usulan suatu proyek diterima dan bila BCR lebih kecil satu (BCR < 1) maka usulan suatu proyek ditolak. Sedangkan bila BCR sama dengan satu $(B C R=1)$ dikatakan proyek tersebut netral[7]. Rumus untuk analisis ini adalah sebagai berikut :

$\mathrm{BCR}=\frac{(P V) B}{\mathrm{Cf}}$

\section{Analisa Sensitivitas}

Analisis sensitivitas merupakan cara untuk mengukur seberapa besar pengaruh variabel variabel yang saling berhubungan jika nilai variabel-variabel itu berubah, bertambah, atau berkurang secara terus-menerus. Analisa sensitivitas dilakukan dengan cara memberi perlakuan yaitu merubah suatu variabel input dalam satuan tertentu, dan mempertahankan nilai variabel-variabel lain pada nilai base case-nya untuk menghasilkan suatu nilai output yang diinginkan. Dalam menghadapi ketidakpastian, analisa sensitivitas seringkali berguna untuk menentukan seberapa besar perubahan sebuah investasi akan memengaruhi keputusan investasi modal. Artinya, seberapa sensitif sebuah investasi tertentu akan berubah akibat perubahan faktor faktor (parameter) tertentu yang tidak diketahui dengan pasti[7].

\section{METODOLOGI}

Penelitian ini berlokasi pada proyek rencana pembangunan rute koneksi kapal Ro-Ro DumaiMalaka di Kota Dumai Propinsi Riau. Penelitian dilakukan dengan metode studi kasus dimana dilakukan analisa data dari suatu objek yang dijadikan kasus. Objek yang menjadi kasus dalam penelitian ini adalah rencana pembangunan rute koneksi kapal Ro-Ro Dumai - Malaka. Data internal dan eksternal proyek tersebut pada tahap awal di olah dengan menggunakan software Microsoft Excel, kemudian diambil data-data yang diperlukan untuk menganalisa kelayakan finansial pada rencana pembangunan rute koneksi kapal Ro-Ro Dumai Malaka.

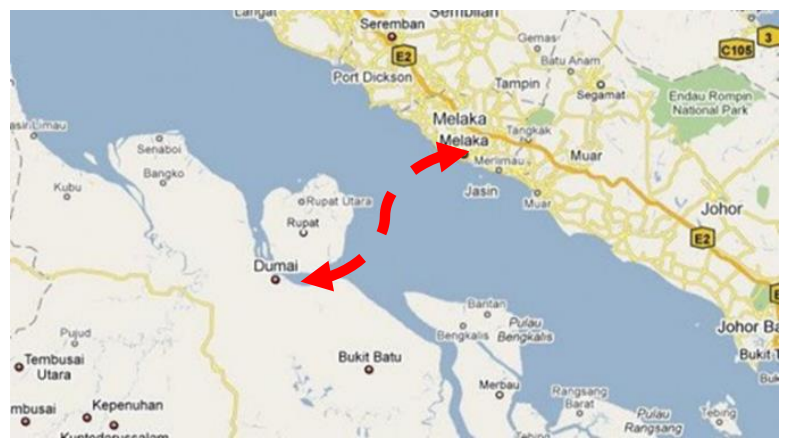

Gambar 1. Rencana Rute Koneksi Kapal Ro-Ro Dumai-Malaka

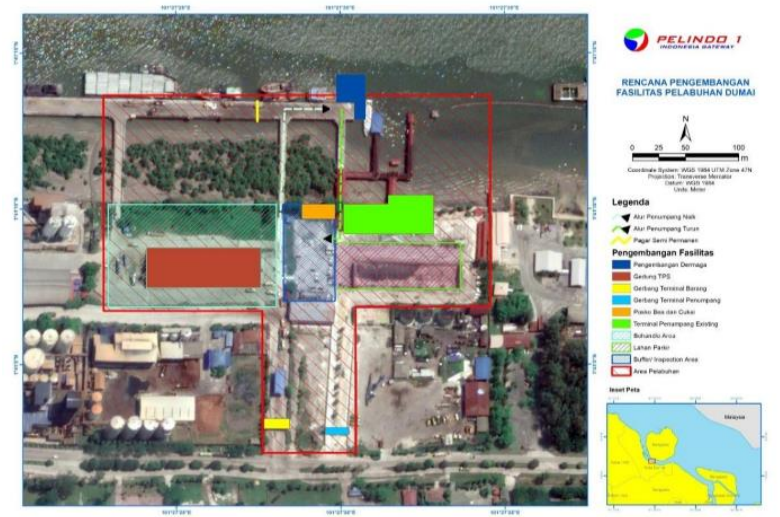

Gambar 2. Site Plan Rencana Pembanguna Pelabuhan Dumai

Data penelitian adalah merupakan data sekunder yang diambil dari dokumen rencana pembangunan rute koneksi kapal Ro-Ro DumaiMalaka. Data teknis yang terkait dengan pelaksanaan pembangunan proyek, meliputi :

a. Biaya investasi proyek, yaitu biaya untuk pembangunan fisik mulai dari desain, konstruksi, supervisi biaya pengadaan tanah/pembebasan lahan jika ada pembebasan lahan, bunga selama masa konstruksi (interest during construction) dan biaya finansial (financing cost).

b. Biaya operasional, yaitu biaya yang digunakan selama pelabuhan berjalan meliputi gaji karyawan dan pengadaan keperluan administrasi pelabuhan

c. Biaya pemeliharaan rutin dan biaya pemeliharaan berkala.

d. Volume lalu lintas penyebrangan (Produktivitas Pelabuhan)

e. Rencana penetapan tarif dasar 
f. Pendapatan diluar penyebrangan (sewa kios, reklame dll)

Data eksternal yang berpengaruh terhadap kelayakan finansial proyek yang terkait dengan indikator ekonomi domestik, antara lain:
a. Laju inflasi
b. Sertifikat Bank Indonesia
c. JIBOR atau INDONIA

Metode pengumpulan data yang digunakan dalam penelitian ini adalah wawancara. Teknik wawancara pada penelitian ini adalah teknik wawancara tidak terstruktur kepada pihak-pihak yang terkait, yaitu pihak PT. Pelindo I (Persero) Cabang Dumai. Wawancara yang dilakukan untuk mengetahui data produktivitas pelabuhan, besaran tarif dasar pelabuhan, umur rencana, biaya investasi, struktur permodalan dan biaya operasional pemeliharaan.

Setelah data terkumpul, dilanjutkan dengan membuat aliran arus kas (cashflow) untuk mengetahui laporan arus kas masuk dan arus kas keluar pada proyek. Tahapan selanjutnya adalah melakukan identifikasi dan permodelan variable resiko yang nantinya akan digunakan sebagai dasar untuk melakukan analisa sensitivitas untuk menganalisa variable apa saja yang berpengaruh dan seberapa besar pengaruhnya terhadap kelayakan finansial proyek.

Untuk analisa finansial dilakukan dengan metode deterministik dengan pendekatan Net Present Value (NPV), Internal Rate Of Return (IRR), dan Benefit Cost Ratio (BCR). Pendekatan deterministik dipilih karena dapat menyatakan bahwa investasi dapat diterima atau ditolak melalui estimasi satu nilai tunggal (single point estimate) sehingga analisa dapat dilakukan secara sederhana.

Tahapan kegiatan penelitian disajikan dalam bentuk bagan alir (flow chart) seperti pada Gambar di bawah ini

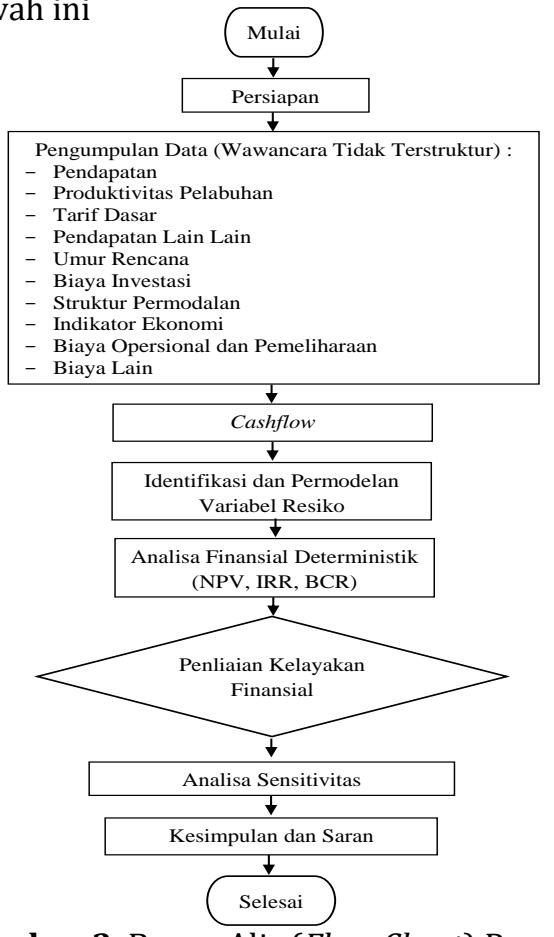

Gambar 3. Bagan Alir (Flow Chart) Penelitian

\section{HASIL DAN DISKUSI}

Masa pembangunan dari proyek ini akan di mulai pada tahun 2020 dan akan selesai di penghujung tahun 2022 serta akan beroperasi pada awal tahun 2023, dengan umur proyek yang diprediksikan dapat mencapai 30 tahun dengan pekerjaan konstruksi anatara lain adalah Pekerjaan Dermaga, Pekerjaan Gudang ,Pekerjaan Lahan Parkir, dan Pekerjaan Posko. Total biaya investasi adalah Rp. 56.702.000.000,00 [14]. Besaran biaya untuk pelaksanaan kajian study kelayakan diasumsikan sebesar $1,00 \%$ dari total biaya konstruksi. Biaya DED diasumsikan sebesar 1,50\% dari total biaya konstruksi. Biaya Konsultan Supervisi diasumsikan sebesar 1,25\% dari total biaya konstruksi. Biaya lainnya yang dapat diasumsikan dapat mencapai 6,00\% dari total biaya konstruksi. Untuk besar biaya operasional menurut PT. Pelindo I (Persero) dan beberapa praktisi diasumsikan sebesar $30 \%$ dari pendapatan pelabuhan tiap tahunnya. Nilai sisa (salvage value) sebesar Rp.2.268.080.000,00 (4,00\% dari total investasi) dan penyusutan tiap tahun adalah Rp.1.814.464.000,00. Rangkuman data investasi dan finansial dapat dilihat pada tabel dibawah ini.

Tabel 1. Rangkuman data biaya investasi dan finansial

\begin{tabular}{|c|c|c|}
\hline & ITEM & BESARAN \\
\hline 1 & Total Biaya Investasi & $\operatorname{Rp} 56.702 .000 .000,00$ \\
\hline \multirow[t]{5}{*}{2} & Lain-lain & \\
\hline & - Nilai sisa & $\begin{array}{l}\text { Rp 2.268.080.000,00 } \\
\text { (4\% Dari Total } \\
\text { Investasi) }\end{array}$ \\
\hline & - Depresiasi & $4,00 \%$ \\
\hline & - Depresiasi per tahun & Rp 1.814.464.000,00 \\
\hline & - PPN & $10 \%$ \\
\hline \multirow[t]{2}{*}{3} & Biaya Operasional dan & 30,00\% Dari \\
\hline & Perawatan & Pendapatan \\
\hline \multirow[t]{3}{*}{4} & Equity \& Debt Ratio & $30 / 70$ \\
\hline & - Equity & $\operatorname{Rp} 17.011 .000 .000,00$ \\
\hline & - Debt & Rp 39.692.000.000,00 \\
\hline 5 & $\begin{array}{l}\text { Periode pengembalian } \\
\text { utang }\end{array}$ & 10 Tahun \\
\hline \multirow[t]{7}{*}{6} & $\begin{array}{l}\text { Tarif Dasar dan Kenaikan } \\
\text { Tarif }\end{array}$ & \\
\hline & -Tarif Pas Penumpang & Rp50.000,00 \\
\hline & -Tarif Pas Masuk Truk & Rp196.650,00 \\
\hline & -Tarif Tambat Kapal & Rp6.370.920,00 \\
\hline & -Tarif Penumpukan Truk & Rp7.500,00 \\
\hline & -Tarif Parkir Pengunjung & Rp4.000,00 \\
\hline & -Kenaikan tarif & $\begin{array}{l}\text { tiap } 2 \text { tahun sesuai } \\
\text { inflasi }\end{array}$ \\
\hline 7 & Penghasilan lain & $\begin{array}{l}1,00 \% \text { Dari Pendapatan } \\
\text { Produktivitas } \\
\text { Pelabuhan }\end{array}$ \\
\hline 8 & Pajak Penghasilan (PPh) & $30 \%$ \\
\hline 9 & $\begin{array}{l}\text { Pajak Bumi dan } \\
\text { Bangunan }\end{array}$ & $1 \%$ \\
\hline 10 & Biaya Pendanaan & $1,25 \%$ \\
\hline 11 & $\begin{array}{l}\text { Discount Rate / Tingkat } \\
\text { Suku Bunga }\end{array}$ & $\begin{array}{l}4,92 \% \text { (rata rata } \\
\text { tingkat suku bunga SBI } \\
2016-2020 \text { ) }\end{array}$ \\
\hline
\end{tabular}




\section{Prediksi Pertumbuhan Jasa Pelabuhan}

Proyeksi Pertumbuhan Produktivitas Jasa Pelabuhan dilakukan dengan identifikasi dan analisis proyeksi demand dan frekuensi dari beberapa input data yaitu kondisi transportasi penyeberangan yang ada (existing), identifikasi permasalahan, dan identifikasi pergerakan penumpang dan barang. Pada awal tahun operasional rencana pada awal tahun 2023 terdapat demand sebanyak 9.489 penumpang per tahun dari Pelabuhan Dumai. Dari sisi barang (cargo) terdapat demand sebanyak 136.871 ton per tahun dari Pelabuhan Dumai. Sementara Pertumbuhan demand penumpang dan barang sebesar $\pm 16,5 \%$ di awal tahun operasional rencana (2023), menurun menjadi $\pm 6,25 \%$ di sepuluh tahun pertama (2033), selanjutnya menurun lagi menjadi $\pm 3,80 \%$ di sepuluh tahun kedua (2043), dan terakhir berada di angka $\pm 3,00 \%$ di tahun akhir tinjauan (2050)[14]. Proyeksi pertumbuhan produktivitas jasa pelabuhan di pelabuhan dumai dapat dilihat pada tabel dibawah ini.

Tabel 2. Prediksi Pertumbuhan Jasa Pelabuhan

\begin{tabular}{llllll}
\hline ITEM & $\mathbf{2 0 2 3}$ & $\mathbf{2 0 2 5}$ & $\mathbf{2 0 3 0}$ & $\mathbf{2 0 4 0}$ & $\mathbf{2 0 5 0}$ \\
\hline Penumpang & 9.489 & 12.168 & 18.865 & 32.259 & 45.653 \\
Kendaraan & 13.076 & 16.213 & 17.575 & 20.300 & 23.025 \\
Tambatan & 212 & 256 & 256 & 256 & 256 \\
Truk Naik & 13.76 & 16.213 & 17.575 & 20.300 & 23.025 \\
Parkir & 110 & 113 & 120 & 135 & 150 \\
\hline
\end{tabular}

\section{Pendapatan Pelabuhan}

Perhitungan pendapatan pelabuhan yang diterima diprediksi berdasarkan kepada 6 asumsi sebagai berikut :

1. Proyeksi Pertumbuhan Produktivitas Jasa Pelabuhan di Pelabuhan Dumai

2. Besar tarif yang akan dikenakan kepada para pemakai jasa pelabuhan, yang akan mengacu kepada tarif dasar yang telah ditetapkan oleh pemerintah dan PT. Pelindo I (Persero). Besarnya tarif juga akan mengalami kenaikan setiap 2 tahun sesuai laju inflasi.

3. Perhitungan pendapatan melalui parkir diasumsikan dengan durasi 3 jam perhari selama 330 hari dalam 1 tahun.

4. Perhitungan pendapatan mulai dihitung pada awal masa operasi pelabuhan yaitu di tahun 2023.

5. Pendapatan lain-lain, diasumsikan sebesar $1,00 \%$ dari total pendapatan tiap tahunnya.

6. Proyeksi pendapatan dihitung selama 30 tahun sesuai dengan umur rencana proyek .

Prediksi pendapatan pelabuhan dapat dilihat pada tabel dan gambar dibawah ini.
Tabel 3. Prediksi Pendapatan Pelabuhan

\begin{tabular}{|c|c|c|c|c|c|}
\hline \multirow{2}{*}{ ITEM } & \multicolumn{5}{|c|}{ PENDAPATAN (Juta Rp.) } \\
\hline & 2023 & 2025 & 2030 & 2040 & 2050 \\
\hline pang & 474,45 & 627,87 & 1.038 & 2.077 & 3.442 \\
\hline Kendaraan & 2.572 & $3.289,7$ & 3.794 & 5.115 & 6.771 \\
\hline Tambatan & 1.350 & $1.681,8$ & 1.788 & 2.085 & 2.431 \\
\hline Truk Naik & 98,07 & 126,46 & 147,63 & 200,97 & 274 \\
\hline Parkir & 435,60 & 447,48 & 475,20 & 534,60 & 594 \\
\hline Lain Lain & 49,31 & 61,73 & 72,43 & 100,14 & 135,14 \\
\hline Total & 4.980 & 6.235 & 7.315 & 10.114 & 13.648 \\
\hline
\end{tabular}

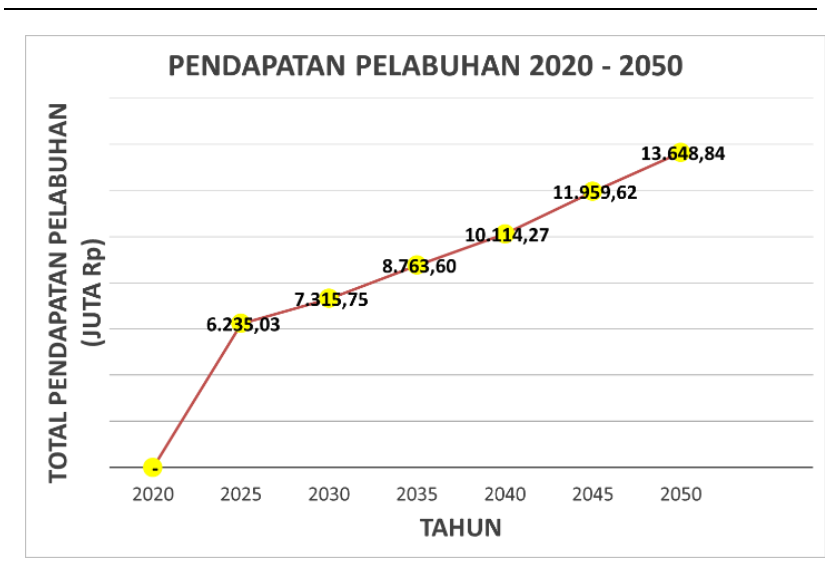

Gambar 4. Grafik Prediksi Pendapatan Pelabuhan Dumai Periode 2020-2050

Dari Tabel 3 dan Gambar 4 dapat dilihat prediksi pendapatan pelabuhan tiap tahunnya dimana pada tahun 2023 pada masa awal pelabuhan beroperasi, pendapatan pelabuhan adalah $\mathrm{Rp} 4.980 .000 .000,00$ dan pada tahun 2050 adalah $\operatorname{Rp} 13.648 .000 .000,00$

\section{Proyeksi Aliran Arus Kas (Cashflow)}

Sebelum dilakukan analisa finansial pada rencana pelaksanaan pembangunan rute koneksi kapal Ro-Ro Dumai - Malaka, maka dilakukan perhitungan proyeksi aliran arus kas (cashflow) berdasarkan kepada 8 asumsi sebagai berikut :

1. Pelabuhan akan mulai beroperasi pada awal tahun 2023. Oleh karena itu, pada tahun 2020 sampai dengan 2022, terjadi arus kas keluar dikarenakan pelabuhan belum beroperasi. Sedangkan arus kas masuk akan dimulai pada tahun 2023.

2. Besar total biaya Feasibility Study pada tahun 2020 adalah 516.640.000,00 dimana 70\% biaya Feasibility Study dari pihak luar atau pinjaman (lihat Tabel 1) sehingga terdapat biaya pendanaan 1,25\% (lihat Tabel 1) dari total biaya Feasibility Study yaitu sebesar $\mathrm{Rp} 4.502 .600,00$. Total biaya investasi Feasibility Study pada tahun 2020 adalah total biaya Feasibility Study ditambah biaya pendanaan yaitu Rp 521.160.600,00.

3. Besar total biaya Detail Engineering Design pada tahun 2021 adalah Rp 774.960.000,00 dimana 70\% biaya 
Detail Engineering Design dari pihak luar atau pinjaman (lihat Tabel 1) sehingga terdapat biaya pendanaan 1,25\% (lihat Tabel 1) dari total biaya Detail Engineering Design yaitu sebesar Rp 6.780.900,00. Total biaya investasi Detail Engineering Design pada tahun 2021 adalah total biaya Detail Engineering Design ditambah biaya pendanaan yaitu Rp 781.740.900,00.

4. Besar total biaya konstruksi, supervisi dan overhead pada tahun 2022 adalah Rp $55.410 .000 .000,00$ dimana $70 \%$ biaya biaya konstruksi, supervisi dan overhead dari pihak luar atau pinjaman (lihat Tabel 1) sehingga terdapat biaya pendanaan $1,25 \%$ (lihat Tabel 1) dari total biaya biaya konstruksi, supervisi dan overhead yaitu sebesar Rp 484.837.500,00. Selain itu terdapat bunga pada saat masa konstruksi (Interest During Construction/IDC) yaitu 7,11\% sehingga besar bunga pada masa konstruksi adalah Rp 3.939.651.000,00. Total biaya konstruksi, supervisi dan overhead pada tahun 2022 adalah Rp 59.834.488.500,00

5. Prediksi pendapatan pelabuhan selama umur rencana (lihat Tabel 3).

6. Biaya operasional dan perawatan diasumsikan sebesar $30 \%$ dari pendapatan pelabuhan tiap tahunnya (lihat Tabel 1).

7. Biaya depresiasi/penyusutan tiap tahun adalah Rp 1.814.464.000,00. (lihat Tabel 1)

8. Net Cash Flow After Taxt adalah adalah total dari nilai arus kas masuk (cash in) dikurangi dengan nilai arus kas keluar (cash out) pada tahun tersebut yang sudah dikurangi dengan Pajak Penghasilan (PPh) sebesar 30\% (lihat Tabel 1).. Arus kas masuk didapat dari besaran pendapatan. Sementara arus kas keluar adalah total dari biaya investasi, biaya depresiasi/penyusutan dan biaya operasional dan perawatan

Proyeksi Aliran Kas selanjutnya ditampilkan dalam Tabel 4, sebagai berikut:

Tabel 4. Proyeksi Aliran Arus Kas (Cashflow)

\begin{tabular}{|c|c|c|c|c|c|}
\hline \multirow[t]{2}{*}{ Tahun } & \multirow[t]{2}{*}{$\mathbf{N}$} & INVESTASI & CASH IN & $\begin{array}{c}\text { CASH } \\
\text { OUT }\end{array}$ & $\begin{array}{c}\text { NET } \\
\text { CASH } \\
\text { FLOW } \\
\text { AFTER } \\
\text { TAX } \\
\end{array}$ \\
\hline & & (Juta Rp.) & (Juta Rp.) & $\begin{array}{l}\text { (Juta } \\
\text { Rp.) }\end{array}$ & $\begin{array}{l}\text { (Juta } \\
\text { Rp.) } \\
\end{array}$ \\
\hline 2020 & FS & 521,16 & - & - & - \\
\hline 2021 & DED & 781,74 & - & - & - \\
\hline 2022 & Konst & $59.834,49$ & - & - & - \\
\hline 2023 & 1 & & $4.980,13$ & $1.494,04$ & $1.714,48$ \\
\hline
\end{tabular}

\begin{tabular}{|c|c|c|c|c|c|}
\hline \multirow[t]{2}{*}{ Tahun } & \multirow[t]{2}{*}{$\mathbf{N}$} & INVESTASI & CASH IN & $\begin{array}{l}\text { CASH } \\
\text { OUT }\end{array}$ & $\begin{array}{c}\text { NET } \\
\text { CASH } \\
\text { FLOW } \\
\text { AFTER } \\
\text { TAX } \\
\end{array}$ \\
\hline & & (Juta Rp.) & (Juta Rp.) & $\begin{array}{l}\text { (Juta } \\
\text { Rp.) }\end{array}$ & $\begin{array}{l}\text { (Juta } \\
\text { Rp.) }\end{array}$ \\
\hline 2024 & 2 & & $5.610,75$ & $1.683,22$ & $2.023,48$ \\
\hline 2025 & 3 & & $6.235,03$ & $1.870,51$ & $2.329,38$ \\
\hline 2030 & 8 & & $7.315,75$ & $2.194,72$ & $2.858,93$ \\
\hline 2031 & 9 & & $7.681,06$ & $2.304,32$ & $3.037,93$ \\
\hline 2035 & 13 & & $8.763,60$ & $2.629,08$ & $3.568,38$ \\
\hline 2036 & 14 & & $8.917,31$ & $2.675,19$ & $3.643,70$ \\
\hline 2040 & 18 & & $10.114,27$ & $3.034,28$ & $4.230,21$ \\
\hline 2041 & 19 & & $10.590,75$ & $3.177,23$ & $4.463,68$ \\
\hline 2045 & 23 & & $11.959,62$ & $3.587,88$ & $5.134,43$ \\
\hline 2046 & 24 & & $12.138,74$ & $3.641,62$ & $5.222,20$ \\
\hline 2050 & 28 & & $13.648,84$ & $4.094,65$ & $5.962,15$ \\
\hline
\end{tabular}

\section{Identifikasi Variabel Resiko}

Pada penelitian ini variabel yang mempunyai resiko dan ketidakpastian yang berpengaruh terhadap kelayakan finansial proyek dapat dilihat pada Tabel 5.

Tabel 5. Identifikasi Variabel Resiko

\begin{tabular}{|c|c|c|}
\hline Variabel & Identifikasi Resiko & Dampak \\
\hline $\begin{array}{l}\text { Indikator } \\
\text { Ekonomi } \\
\text { (Sertifikat Bank } \\
\text { Indonesia, Laju } \\
\text { inflasi, Jakarta } \\
\text { Inter Offered } \\
\text { Rate) }\end{array}$ & $\begin{array}{l}\text { Perilaku pasar tidak } \\
\text { stabil dan regulasi } \\
\text { pemerintah }\end{array}$ & $\begin{array}{l}\text { Biaya } \\
\text { investasi }\end{array}$ \\
\hline $\begin{array}{l}\text { Volume Proyeksi } \\
\text { Pertumbuhan } \\
\text { Produktivitas } \\
\text { Jasa Pelabuhan }\end{array}$ & $\begin{array}{l}\text { Prediksi } \\
\text { pertumbuhan } \\
\text { produktivitas jasa } \\
\text { pelabuhan di } \\
\text { pelabuhan dumai, } \\
\text { yang berpengaruh } \\
\text { pada pendapatan }\end{array}$ & $\begin{array}{l}\text { Pendapatan } \\
\text { pelabuhan }\end{array}$ \\
\hline $\begin{array}{l}\text { Biaya } \\
\text { operasional dan } \\
\text { pemeliharaan }\end{array}$ & $\begin{array}{l}\text { Biaya tenaga kerja, } \\
\text { biaya pemeliharaan } \\
\text { rutin, biaya utilitas/ } \\
\text { operasional dan } \\
\text { biaya lainnya } \\
\text { selama pelabuhan } \\
\text { beroperasi }\end{array}$ & $\begin{array}{l}\text { Biaya } \\
\text { investasi }\end{array}$ \\
\hline $\begin{array}{l}\text { Biaya Feasibility } \\
\text { Study dan } \\
\text { Perencanaan } \\
\text { (DED) }\end{array}$ & $\begin{array}{l}\text { Perubahan design } \\
\text { yang berpengaruh } \\
\text { pada waktu dan } \\
\text { biaya konstruksi }\end{array}$ & $\begin{array}{l}\text { Biaya } \\
\text { investasi }\end{array}$ \\
\hline Biaya konstruksi & $\begin{array}{l}\text { Biaya selama } \\
\text { pekerjaan } \\
\text { konstruksi } \\
\text { berlangsung }\end{array}$ & $\begin{array}{l}\text { Biaya } \\
\text { investasi }\end{array}$ \\
\hline
\end{tabular}

Analisis risiko dengan meng-kuantifikasi efek dari risiko yang diidentifikasi dalam bentuk variabel finansial dapat dilakukan dengan 
pendekatan deterministik dan stokastik, perbedaan antara deterministik dan stokastik adalah jika deterministik menunjukkan satu nilai (numerik) dalam perhitungan analisis risiko, sedangkan stokastik memberikan hasil beberapa kemungkinan (probabilitas) yang realistis dari risiko [13].

Hasil dari identifikasi variabel resiko ini nantinya akan menjadi variabel input untuk analisa sensitivitas yang menghasilkan variabel yang paling sensitif (berpengaruh) terhadap kelayakan finansial.

\section{Perhitungan Analisa Kelayakan Finansial}

Setelah membuat proyeksi aliran arus kas (cashflow), dilanjutkan dengan analisa kelayakan finansial secara deterministik (single point estimate) dengan metode Net Present Value (NPV), Internal Rate of Return (IRR) dan Benefit-Cost Ratio (BCR). Hasil Perhitungan Indikator Kelayakan Finansial Proyek dapat dilihat pada Tabel 6 dibawah ini.

Tabel 6. Hasil Indikator Kelayakan Finansial

\begin{tabular}{lll}
\hline $\begin{array}{c}\text { Indikator } \\
\text { Kelayakan }\end{array}$ & \multicolumn{1}{c}{ Nilai } & \multicolumn{1}{c}{ Keterangan } \\
\hline NPV & -Rp 11.520.558.961 & NPV negatif, \\
& & NPV $<0$ \\
IRR & $3,75 \%$ & IRR $<$ Tingkat \\
& & Suku Bunga \\
BCR & 0,831882091 & BCR $<1$ \\
\hline
\end{tabular}

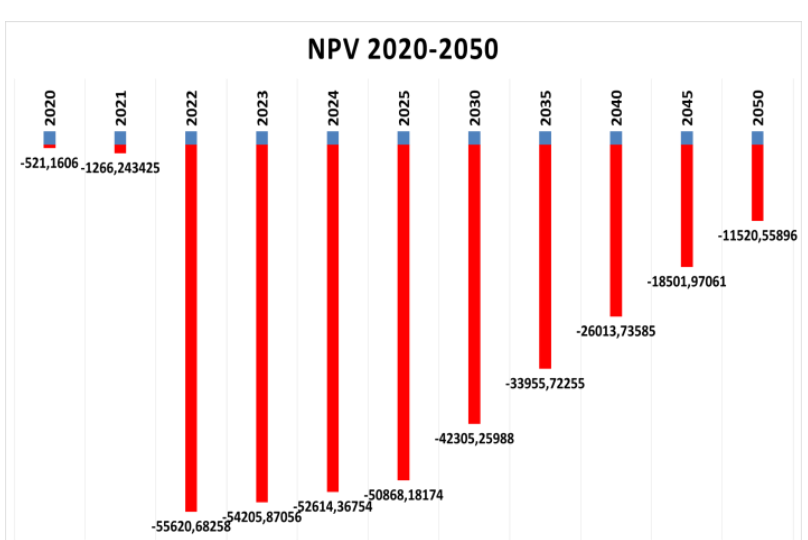

Gambar 5. Net Present Value Periode 2020-2050

Hasil Net Present Value yang diperoleh pada akhir umur rencana pada tahun 2050 didapat hasil Rp.-11.520.558.961. Karena menghasilkan Net Present Value yang bernilai negatif, maka dapat dinyatakan bahwa rencana pembangunan rute koneksi kapal Ro-Ro Dumai-Malaka tidak layak secara finansial.

Selanjutnya hasil Internal Rate of Return (IRR) di dapatkan nilai IRR adalah 3,75\%, lebih kecil dari nilai discount rate yaitu 4,92\%. IRR yang lebih kecil dari discount rate memberi gambaran bahwa investasi yang dilakukan akan menghasilkan return lebih kecil dari yang ditargetkan.

Dan hasil Benefit Cost Ratio (BCR) didapatkan hasil nilai BCR kurang dari 1 yang mengartikan bahwa proyek tidak akan memberikan keuntungan pada akhir umur rencana. Dari hasil tersebut, maka dapat dinyatakan bahwa rencana pelaksanaan pembangunan rute koneksi kapal Ro-Ro DumaiMalaka tidak layak secara finansial.

\section{Analisa Sensitivitas}

Analisa sensitivitas dilakukan secara manual menggunakan spreadsheet dari Microsoft Excel yang hasil (output) akan dipresentasikan dalam bentuk diagram laba-laba (spider diagram). Metode analisanya adalah dengan cara merubah suatu variabel input dalam satuan persen (\%) dan mempertahankan nilai variabel input lain pada nilai aslinya. Batasan perubahan variabel input pada nilai $-40 \%$ hingga $+40 \%$ dengan interval $10 \%$. Variabel yang dirubah adalah berdasarkan hasil dari identifikasi variabel resiko (lihat Tabel 5). Hasil analisa sensitivitas dapat dilihat pada Gambar 6 dibawah ini:

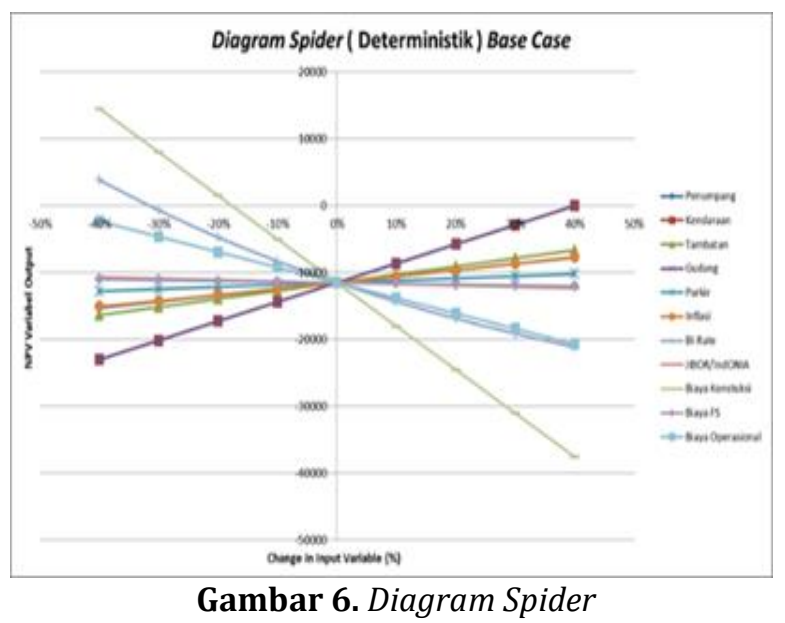

Tabel 7. Nilai NPV Hasil Analisa Sensitivitas

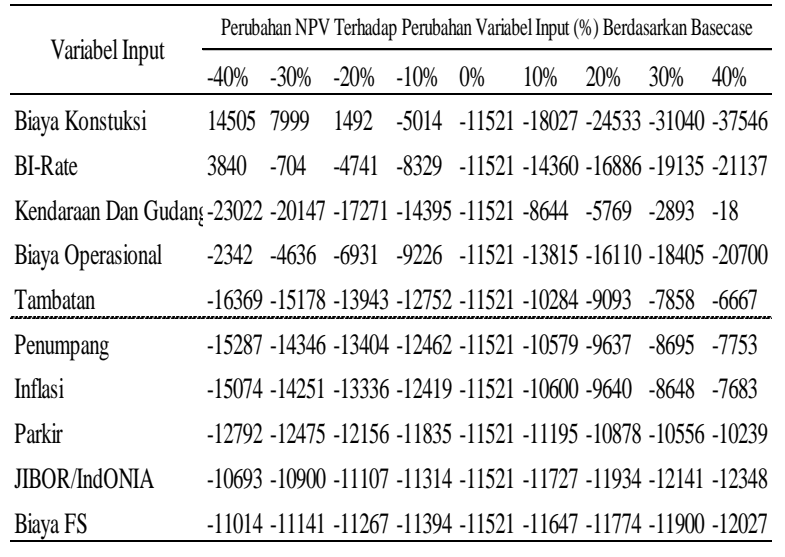

Berdasarkan hasil analisa sensitivitas pada rencana pembangunan rute koneksi kapal Ro-Ro Dumai-Malaka menghasilkan yang paling sensitif (berpengaruh) yaitu Biaya Konstruksi. Hal ini terlihat apabila Biaya Konstruksi Dermaga dan Fasilitas Pelabuhan berkurang 40\%, maka NPV yang diperoleh adalah Rp. 14.505.000.000 pada akhir umur rencana yaitu pada tahun 2050. Selain itu, apabila Biaya Konstruksi Dermaga dan Fasilitas 
Pelabuhan bertambah 40\%, maka NPV yang diperoleh Rp.-37.546.000.000 pada akhir umur rencana.

\section{KESIMPULAN}

Dari hasil analisa kelayakan finansial secara deterministik (single point estimate) dengan metode Net Present Value (NPV), Internal Rate of Return (IRR) dan Benefit-Cost Ratio (BCR), maka dapat dinyatakan bahwa rencana pelaksanaan pembangunan rute koneksi kapal Ro-Ro DumaiMalaka tidak layak secara finansial. Dari hasil tersebut, maka dibutuhkan skenario usulan untuk menunjang agar rencana pembangunan rute koneksi kapal Ro-Ro Dumai-Malaka layak secara finansial

\section{REFERENSI}

[1] ASEAN Secretariat, "Master Plan of ASEAN Connectivity", 2010. [Online]. Available: http://www.asean.org/storage/images/ASEAN _RTK_2014/4_Master_Plan_on_A SEAN_Connectivity.pdf. [Accessed Feb. 14, 2021].

[2] Japan Internasional Cooperation Agency, The Master Plan and Feasibility Study on The Establishment of an Asean Roll-on/ Roll-Off (RoRo) Shipping Network and Short Sea Shipping, Final Report, Volume 2-Development Potentials, Directions and Plannings, 2013.

[3] I Ketut Mudana, 2014, "Pengoperasian Lintas Penyeberangan Bitung (Sulawesi Utara) Davao Dan Santos City (Filipina) Dalam Mewujudkan Konektivitas Asean" Badan Litbang Perhubungan, Jakarta

[4] Danny Faturachman, 2017, "Analisis Transportasi Penyeberangan Laut Antar Negara Asean (Indonesia, Malaysia, Thailand) Studi Kasus: Penyeberangan Antar Negara Dipulau Sumatera (Belawan - Penang Phuket)", Jurnal Sains dan Teknologi, Volume VII. No. 1. Maret 2017, Fakultas Teknologi Kelautan, Universitas Darma Persada

[5] Keputusan Menteri Perhubungan Nomor KM. 52 Tahun 2004 Tentang Penyelenggaraan Pelabuhan Penyeberangan

[6] Soejono, Sistem dan Prosedur Kerja, Jakarta, Bumi Aksara, 2000.

[7] Husnan, Suad dan Suwarsono Muhammad, Studi Kelayakan Proyek. Edisi Keempat, Penerbit UPP AMP YKPN, Yogyakarta, 2000.

[8] Haming, Murdifin dan Salim Basalamah, Studi Kelayakan Investasi: Proyek dan Bisnis. Cetakan-1, Penerbit PPM, Jakarta, 2003.

[9] Pusat Pendidikan Dan Pelatihan Sumber Daya Air Dan Kontruksi, Modul 5 - Kelayakan Finansial, Pusdiklat SDA dan Konstruksi, Bandung, 2017.

[10] Robinson, T. R., Henry, E., dkk. 2015. "International Financial Statement Analysis,
Third Edition". New Jersey: CFA Institute Investment Series.

[11] Damodaran, Aswath, Investment Valuation (2nd ed), John Wiley \& Sons, New York, 2002.

[12] Ari Sandhyavitri, Alfian Malik,Imam Suprayogi, Manyuk Fauzi, Ridwan Rahman, Risk and Uncertainty in the Medan - Binjai Toll Road Infrastructure Project, Indonesia Based on the Stochastic Analizes, Ejers, European Journal of Engineering Research and Science, Vol. 3 No. 6 , Juni 2018, Pekanbaru, 2018.

[13] PT. Pelindo 1 (Persero) Cabang Dumai, Ringkasan Eksekutif Penyusunan Feasibility Study untuk Pengembangan Koneksi Ro-Ro dan Potensi Kerjasama Bisnis Kepelabuhanan dan Logistik Koneksi Ro-Ro Pelabuhan Dumai - Tanjung Bruas Melaka, 2020.

[14] Hery, 2012, "Akuntansi Keuangan Menengah 1", Cetakan Kedua, Edisi Pertama, Bumi Aksara, Jakarta.

[15] Horngren, Charles T., Walter T. Harrison Jr., 2007, "Akuntansi. Edisi 7. " (Diterjemahkan oleh: Gina Gandia dan Danti Pujiati), Erlangga, Jakarta.

[16] Kasmir, \& Jakfar, 2003," Studi Kelayakan Bisnis", Predana Media Grup, Jakarta

[17] Brigham, F dan Houston, J. 2001. "Dasar-Dasar Manajemen Keuangan. Edisi 8, Buku 2", Salemba Empat, Jakarta

\section{NOMENKLATUR}

$\begin{array}{ll}\mathrm{B} \mathrm{t} & =\text { Aliran kas masuk tahun ke-t } \\ \mathrm{C} \mathrm{t} & =\text { Aliran kas keluar tahun ke-t } \\ \mathrm{t} & =\text { Periode waktu } \\ \mathrm{i} & =\text { Tingkat suku bunga } \\ \mathrm{At} & =\text { Aliran kas pada periode t } \\ \mathrm{r} & =\text { Tingkat suku bunga } \\ \mathrm{n} & =\text { Periode terakhir aliran kas diharapkan } \\ \mathrm{S} & =\text { Jumlah aliran kas yang di "discounted" } \\ & \text { kan pada akhir sampai tahun } \mathrm{n} \\ \mathrm{BCR} & =\text { Ratio manfaat terhadap biaya. } \\ \mathrm{(PV)B} & =\text { Nilai sekarang benefit. } \\ \mathrm{Cf} & =\text { Nilai sekarang biaya. }\end{array}$

